\title{
Klasifikasi Frase Nama-Nama Menu Makanan Berbahasa Inggris di Koran Minggu Ini
}

\author{
Wiwiek Sundari \\ Fakultas Ilmu Budaya, Universitas Diponegoro \\ wiekku@yahoo.com
}

\begin{abstract}
The language structure comprehension is closely related to the branch of linguistics that is syntax. This research studies the classification of the English food menu names taken from weekly newspaper Cempaka. The objective of this research is to describe the classification of English food menu names. Theory used in this research is based on Hockett and Brown \& Miller's. The result of this qualitative research shows that the classification of English food menu names are two classes, Noun Phrases and Possesive Phrases.
\end{abstract}

Keywords : word, phrase, determiner, noun, possesive.

\section{Intisari}

Pemahaman struktur bahasa sangat erat kaitannya dengan cabang linguistic, terutama sintaksis. Penelitian ini mengkaji klasifikasi nama menu makanan bahasa Inggris yang diambil dari surat kabar mingguan Cempaka. Tujuan penelitian ini adalah mendeskripsikan klasifikasi nama menu makanan bahasa Inggris. Teori yang digunakan dalam penelitian ini didasarkan pada Hockett dan Brown \& Miller's. Hasil penelitian kualitatif ini menunjukkan bahwa klasifikasi nama menu makanan bahasa Inggris ada dua kelas, frase nomina dan frase possesif.

Kata kunci: kata, frase, determinator, kata benda, possesif

\section{Pendahuluan}

Bahasa mempunyai unsur yang paling penting di dalamnya yaitu kata. Bahasa manusia di manapun di dunia ini terbentuk dari rangkaian kata-kata atau kelompok kata. Bahasa sebagai sarana atau alat yang penting yang dapat digunakan dalam bidang politik, sosial, kebudayaan, ekonomi dan perdagangan. Bahasa itu dianggap penting selama masih ada orang atau masyarakat yang menggunakan bahasa tersebut.

Bahasa yang masih digunakan oleh pemakai bahasa tersebut masuk dalam kategori bahasa hidup (living language), sedangkan bahasa yang tidak digunakan 
lagi atau tidak dipakai sebagai sarana komunikasi bahasa tersebut disebut bahasa mati (dead language) (Baught, 1957). Ciri dari bahasa hidup adalah selalu terjadi perubahan, baik dalam tata bahasa (grammar) maupun kosa kata (vocabulary). Perubahan yang paling menonjol atau yang mudah diketahui yaitu perubahan dalam bidang kosakata. Banyak kosa kata atau kata-kata baru tercipta atau terbentuk dalam segala bidang seperti dalam bidang teknologi, politik, ekonomi dan perdagangan (Barber, 1999). Kosa kata dalam berbagai bidang ini termasuk dalam kategori content word. Content word bersifat terbuka. Dengan kata lain, kelas kata ini masih bisa bertambah jumlahnya seiring dengan perkembangan zaman dan teknologi.

Bahasa yang masuk dalam kategori bahasa hidup pasti mengalami perkembangan dan evolusi. Bahasa sebagai suatu realitas yang terus berkembang memang sangat menarik untuk dikaji khususnya kata sebagai unsur terpenting dalam bahasa. Perkembangan kata yang ada dalam bahasa berhubungan langsung dengan evolusi intelektual dan sosial manusia. Puluhan bahkan ratusan kata baru tercipta sesuai dengan fungsinya. Kata-kata baru banyak ditemukan dalam dunia bisnis termasuk dalam bisnis makanan, yaitu pada nama-nama menu makanan yang merupakan salah satu hasil evolusi intelektual atau kreasi manusia. Kreativitas pembentukan kata dalam bidang menu mengalami perkembangan yang begitu pesat, sehingga banyak nama-nama menu yang lebih menarik, inovasi dan kreatif sehingga dapat memperngaruhi konsumen atau orang untuk membeli atau mencoba menu tersebut.

Bila diperhatikan, terdapat berbedaan dalam pemberian nama-nama menu pada tahun 80-an dibandingkan dengan pemberian nama-nama menu pada jaman sekarang. Pada tahun 80-an nama-nama menu masih bersifat tradisional atau nasional maksudnya yaitu nama-nama menu pada waktu itu masih murni menggunakan bahasa Indonesia, seperti misalnya nasi goreng, jagung bakar, telur dadar, ayam goreng dan lain-lain. Namun pada jaman sekarang nama-nama menu sudah mengalami perubahan, nama menu tersebut bersifat internasional karena nama-nama menu jaman sekarang banyak menggunakan bahasa asing, seperti fried rice, popcorn, omelette, fried chicken. 
Nama-nama menu tersebut bisa dijumpai atau dibaca pada media cetak seperti tabloid, koran, majalah, buku-buku masakan, restoran dan kafe. Kata-kata baru tersebut terbentuk melalui berbagai proses pembentukan kata yang menarik untuk dianalisis secara lebih mendalam. Selain itu nama-nama menu itu juga menarik untuk dianalisis dari sudut pandang sintaksis yaitu struktur frasa atau kalasisikasi frase. Oleh karena itu penulis sangat tertarik untuk melakukan penelitian mengenai klasifikasi frase dengan data nama menu makanan yang terdapat di media cetak bukan di restaurant atau di hotel-hotel. Selain itu nama dan menu yang akan di analisis adalah nama-nama menu yang berbahasa Inggris bukan yang berbahasa lain seperti Korea, Jepang, Jawa, Indonesia atau Prancis.

Media cetak yang memuat nama-nama menu makanan berbahasa Inggris adalah koran minggu ini Suara Merdeka. Koran minggu ini terbit satu minggu sekali dan memberikan berbagai informasi di Jawa Tengah pada umumnya atau di Semarang pada khususnya.

Alasan mengapa penulis melakukan penelitian mengenai nama-nama menu makanan di koran minggu ini Suara Merdeka karena koran ini sering menyajikan nama-nama menu makanan berbahasa Inggris yang diambil dari berbagai hotel berbintang di Semarang. Selain itu nama-nama menu berbahasa Inggris yang diambil sebagai data penelitian supaya data tersebut lebih spesifik dan akurat karena tidak dipadukan dengan nama-nama menu dari bahasa lain. Dengan namanama menu makanan yang hanya berbahasa Inggris di harapkan penelitian ini bisa memperoleh tingkat objektifitas yang tinggi.

Nama-nama menu makanan berbahasa Inggris yang terdapat di koran minggu ini Suara Merdeka merupakan pokok permaslahan dalam penelitian ini. Nama-nama menu tersebut akan di bahas secara khusus dari sudut pandang sintaksis yaitu tentang klasifikasi frase. Pembatasan masalah dalam penelitian ini sangat diperlukan, oleh karena itu masalah yang akan di bahas adalah bagaimana klasifikasi frase nama-nama menu makanan di koran minggu ini Suara Merdeka.

Sintaksis merupakan cabang linguistik yang mempelajari susunan kata dalam frase dari kalimat, seperti yang dikemukakan oleh Ramelan (1991: 131) "syntax is the study of the arrangement of words into phrases and sentences or 
syntactical construction and the smallest units to be arranged are words" hal ini didukung oleh Kencana (2005: 123) yang mengatakan sintaksis merupakan bagian dari sub sistem tata bahasa atau gramatika yang menelaah struktur satuan bahasa yang lebih besar dari kata mulai dari frase hingga kalimat. Dengan demikian bisa dikatakan bahwa sintaksis merupakan studi gramatika struktur kata. Struktur kata yang dimaksud di sini adalah urutan kata. Sebagian besar makna suatu frase bergantung pada urutan kata pembentuknya.

Untuk menentukan klasifikasi frase nama-nama menu makanan berbahasa Inggris, Penulis menggunakan teori-teori yang dikemukakan oleh Baker (1989), Brown \& Miller (1991) dan Hockett (1958). Menurut mereka frase dapat diklasifikasikan menjadi dua bagian, yaitu klasifikasi frase berdasarkan jenis kata yang menjadi unsur inti dan klasifikasi frase berdasarkan hubungan unsur dalam struktur frase.

Klasifikasi frase berdasarkan jenis kata yang menjadi unsur inti atau head frase dibagi menjadi frase nomina, frase verba, frase ajektive, frase preposisi, frase adverbia, frase infinitif, frase gerundif dan frase posesif. Berikut penjelasan masing-masing frase itu.

Frase nomina adalah frase yang unsur inti atau headnya berupa kata benda (noun). Frase Verba merupakan kelompok kata yang headnya atau unsur intinya berupa kata kerja. Frase adjektif adalah frase yang headnya berupa kata sifat. Frase proposisi adalah frase yang kata inti atau headnya berupa preposisi. Frase adverbial menurut Brown \& Miller (1991: 261) adalah frase yang terbentuk dari adverb yang biasanya terletak setelah verba atau adverbial yang lain. Frase Infinitif adalah frase yang terbentuk dengan menambahkan penenanda infinitif to dan diikuti Frase verba. Frase Gerundif menurut Beker (1989: 147) bisa terdiri dari frasa nomina genetif yang diikuti frase verba present participle atau kata kerja present participle yang berdiri sendiri. Frase Posesif adalah frase yang dibentuk dari frase benda yang didikuti oleh penanda kepemilikan -'s.

Menurut Hocckett (1958) klasifikasi frase berdasarkan hubungan dalam struktur dapat dibedakan menjadi dua yaitu frase endosentris dan frase 
eksosentris. Frase endosentris dapat dibedakan menjadi frase endosentris atributif atau modifikatif yaitu frase yang hanya mempunyai satu head atau inti kata yang dapat di ikuti oleh modifikator. Frase endosentris koordinatif adalah frase yang terdiri unsur-unsur yang setara yang dapat dihubungkan oleh konjungsi. Frase endosentris apositif yaitu frase yang mempunyai dua inti dan kedua inti tersebut tidak mempunyai referensi yang sama, inti yang kedua memberi penjelasan pada inti yang pertama.

Frase eksosentris dapat di bedakan menjadi frase eksosentris direktif, frase eksosentris konektif dan frase eksosentris predikatif. Frase eksosentris direktif adalah frase yang unsurnya terdiri dari director atau axis atau objek. Frase eksosentris konektif yaitu frase yang terdiri dari dua unsur, unsur yang pertama berupa verba copula/to be dan unsur yang kedua berupa komplemen. Frase eksosentris predikatif adalah frase yang unsur-unsurnya terdiri dari subjek dan predikat.

Penelitian tentang nama-nama menu makanan berbahasa Inggris yang ada di koran minggu ini Suara Merdeka bertujuan untuk menjelaskan klasifikasi frase nama-nama menu makananan berbahasa Inggris tersebut. Penelitian ini semoga bermanfaat untuk perkembangan ilmu pengetahuan linguistik khususnya dan dalam bidang ilmu sintaksis yaitu frase. Dalam bidang kepraktisan, penelitian di harapkan dapat bermanfaat bagi mereka yang berusaha dalam bisnis makanan atau minuman sehingga mereka mempunyai ide-ide baru untuk menciptakan namanama menu makanan atau minuman yang lebih menarik.

\section{Metode Penelitian}

Penelitian ini menggunakan metode deskriptif yaitu memberikan gambaran mengenai klasifikasi frase nama menu makanan berbahasa Inggris di koran minggu ini Suara Merdeka. Penelitian ini juga merupakan penelitian kualitatif karena penelitian ini berusaha menggambarkan data dengan kata-kata atau kalimat bukan dengan angka-angka. Data dalam penelitian ini adalah data primer yaitu data yang diperoleh langsung sebagai hasil pengumpulan penulis sendiri yang berupa kata atau frase nama-nama menu makanan berbahas Inggris, Metode yang 
digunakan dalam mengumpulkan data adalah metode simak dengan teknik lanjutan berupa teknik catat. Dalam pengambilan sampel penulis menggunakan teknik Random Sampling yaitu pengambilan sampel secara acak di mana setiap individu memiliki kesempatan untuk dipilih menjadi sampel.

Metode yang digunakan untuk yang menganilisis data adalah metode agih dengan teknik lanjutan berupa teknik balik. Teknik ini dilaksanakan dengan cara membalik unsur satuan lingual data penelitian. Selain teknik balik, penelitian juga menggunakan teknik ganti untuk menganalisis klasifikasi frase nama-nama menu makanan. Teknik analisis data ini dilakukan dengan mengganti unsur satuan lingual data penelitian

\section{Pembahasan}

Dari hasil analisis 200 nama menu makanan berbahasa Inggris di Koran minggu ini Suara Merdeka menunjukkan bahwa hanya ada dua kelas frase, yaitu frase nomina dan frase posesif. Frase yang lain seperti frase verba, frase adjektiva, frase adverbia, frase infinitif, frase gerundif, frase proposisi tidak ditemukan. Tabel berikut menunjukkan persentase tipe frase nama-nama menu makanan berbahasa Inggris di koran minggu ini Suara Merdeka.

Tabel klasifikasi frase Nama Menu Makanan

\begin{tabular}{|c|l|c|c|}
\hline NO & \multicolumn{1}{|c|}{ TIPE FRASE } & JUMLAH & PERSENTASE \\
\hline 1 & FRASE NOMINA & 198 & $99 \%$ \\
\hline 2 & FRASE POSESIF & 2 & $1 \%$ \\
\hline 3 & FRASE VERBA & 0 & $0 \%$ \\
\hline 4 & FRASE AJEKTIVA & 0 & $0 \%$ \\
\hline 5 & FRASE ADVERBIA & 0 & $0 \%$ \\
\hline 6 & FRASE INFINITIF & 0 & $0 \%$ \\
\hline 7 & FRASE GERUNDIF & 0 & $0 \%$ \\
\hline 8 & FRASE PROPOSISI & 0 & $0 \%$ \\
\hline & JUMLAH & 200 & $100 \%$ \\
\hline
\end{tabular}

Tabel di atas menunjukkan bahwa dari 200 nama menu makanan berbahasa Inggris di koran minggu ini Suara Merdeka, ditemukan 198 (99\%) frase nomina dan $2(1 \%)$ frase posesif. Enam jenis frase yang lain yaitu frase verba, frase 
ajektiva, frase adverbia, frase infinitif, frasegerundif, dan frase preposisi tidak ditemukan.

Frase nomina nama-nama menu makanan berbahasa Inggris di koran minggu ini Suara Merdeka dapat ditemukan pada: fresh salad, bakes lasagna, cheese pizza, dan chicken noodle. Berikut paparan frase nomina nama-nama menu itu. Fresh salad, nama menu ini termasuk frase nomina yang terbentuk dari modifier dan head. Modifier dalam frase fresh salad berupa adjektif murni (fresh), sedangkan nomina (salad) berfungsi sebagai head. Susunan adjektiva (modifier) yang mendahului nomina (head) sesuai dengan kaidah pembentukan frase nomina dalam bahasa Inggris. Dengan demikian nama menu makanan fresh salad merupakan frase nomina.

Baked Lasagna termasuk frase nomina yang terbentuk dari modifier dan head. Modifier dalam baked lasagna berupa adjektif derivasi (adjektif yang dibentuk dari verba), sedangkan nomina (lasagna) berfungsi sebagai head. Susunan adjektiva (modifier) yang mendahului nomina (head) sesuai dengan kaidah pembentukan frase nomina dalam bahasa Inggris. Dengan demikian nama menu makanan baked lasagna merupakan frase nomina. Nama menu makanan cheese pizza termasuk frase nomina yang terbentuk dari nomina dan nomina. Nomina cheese berfungsi sebagai modifier dalam cheese pizza, sedangkan nomina (pizza) berfungsi sebagai head. Susunan nomina (modifier) yang mendahului nomina (head) sesuai dengan kaidah pembentukan frase nomina dalam bahasa Inggris. Dengan demikian nama menu makanan cheese pizza merupakan frase nomina.

Frase posesif nama-nama menu makanan berbahasa Inggris di koran minggu ini Suara Merdeka dapat ditemukan pada: Papa Ron's pan pizza dan Kid's snack. Berikut paparan frase posesif nama-nama menu itu.

- Papa Ron's pan pizza

Nama menu Papa Ron's pan pizza dikatakan sebagai frase posesif. Hal ini dikarenakan struktur frase ini mengandung unsur posesif yaitu's (Papa 
Ron's). Dengan adanya unsur posesif ini, nama menu Papa Ron's pan pizza dapat dikategorikan sebagai frase posesif.

Unsur posesif juga ditemukan pada nama menu makanan Kid's snack.

\section{- Kid's snack}

Nama menu Kids's snack dikatakan sebagai frase posesif. Hal ini dikarenakan struktur frase ini mengandung unsur posesif yaitu 's (Kid's). Dengan adanya unsur posesif ini, nama menu Kid's snack dapat dikategorikan sebagai frase posesif.

\section{Simpulan}

Simpulan dari hasil analisis penelitian tentang nama-nama menu makanan berbahasa Inggris di koran minggu ini Suara Merdeka, dengan data sampel 200 nama-nama menumakanan, hanya ditemukan dua kelas frase dalam penelitian ini yaitu Frase Nomina dan Frase Posesif. Frase Nomina berjumlah 198 dan Frase Posesif berjumlah 2. Frase nama-nama menu makanan berbahasa Inggris di koran minggu ini Suara Merdeka mengalami penyimpangan baik dalam unsur-unsur pembentuk frase nomina maupun susunan unsur-unsur pembentuk frase nomina

\section{Daftar Pustaka}

Badudu, Abdul Muis. 2005. Morfosintaksis. Jakarta: PT. Rineka Cipta.

Baker, C.L. 1989. English Syntax. Cambridge: The MITT Press.

Baugh, Albert C. 1957. A History of English Language. New York: Appleton Century Inc.

Brown, Keith \& Miller, Jim. 1991. Syntax: A Linguistics Introduction to Sentence Structure. London: Rootledge.

Hockett, Charles F. 1958. A Course in Modern Linguistics. New York: The Mc. Milan Company.

Ramelan. 1992. Introduction to Linguistics Analysis. Semarang: IKIP Semarang Press. 
Sudaryanto. 1993. Metode dan Aneka Teknik Analisis Bahasa (Pengantar Penelitian Wahana Kebudayaan Secara Linguistik). Yogyakarta: Duta Wacana University Press.

Sundari, Wiwiek. 2008. Proses Pembentukan Nama-nama Menu Makanan Berbahasa Inggris di Koran minggu ini Suara Merdeka. Tesis. Program Pascasarjana Linguistik. Semarang. Universitas Diponegoro. 